\title{
A Long-term Follow-up Study on the Engraftment of Human Hematopoietic Stem Cells in Sheep
}

\author{
Tomoyuki ABE 1,2), Yutaka HANAZONO 1,3), and Yoshikazu NAGAO 2) \\ 1)Division of Regenerative Medicine, Center for Molecular Medicine, Jichi Medical University, 3311-1 Yakushiji, \\ Shimotsuke-shi, Tochigi 329-0498, Japan \\ 2) University Farm, Department of Agriculture, Utsunomiya University, 443 Shimokomoriya, Mouka-shi, Tochigi \\ 321-4415, Japan \\ ${ }^{3)}$ CREST, Japan Science and Technology Agency, 5-3 Yonbancho, Chiyoda-ku, Tokyo 102-8666, Japan
}

\begin{abstract}
Xenograft models of human hematopoiesis are essential to the study of the engraftment and proliferative potential of human hematopoietic stem cells (HSCs) in vivo. Immunodeficient mice and fetal sheep are often used as xenogeneic recipients because they are immunologically naive. In this study, we transplanted human HSCs into fetal sheep and assessed the long-term engraftment of transplanted human HSCs after birth. Fourteen sheep were used in this study. In 4 fetal sheep, HSCs were transduced with homeo-box B4 (HOXB4) gene before transplantation, which promoted the expansion of HSCs. Another 4 fetal sheep were subjected to non-myeloablative conditioning with busulfan. Seven of these 8 sheep showed successful engraftment of human HSCs (1-3\% of colonyforming units) as assessed after the birth of fetal sheep ( 5 months post-transplantation), although HOXB4-transduced HSCs showed sustained engraftment for up to 40 months. Intact HSCs were transplanted into six non-conditioned fetal sheep, and human colony-forming units were not detected in the sheep after birth. These results suggest that, as compared with mouse models, where the short lifespan of mice limits long-term follow-up of HSC engraftment, the fetal sheep model provides a unique perspective for evaluating long-term engraftment and proliferation of human HSCs.

Key words: engraftment, hematopoietic stem cells, large animal models, long-term follow-up, sheep
\end{abstract}

\section{Introduction}

Animal transplantation models are indispensable for functional assessment of hematopoietic stem cells (HSCs), because reliable in vitro surrogate assays for the cells capable of long-term hematopoietic repopulation in vivo are currently unavailable $[8,11]$. As experimental transplantation of HSCs into humans is ethically unattainable, xenograft models are commonly used for studying engraftment and proliferative potential of human HSCs in vivo. Several xenogeneic transplantation models have been studied, of which immunodeficient mice $[5-7,9,15]$ and fetal sheep [31] are advantageous because of their immunologically naive state. Human HSCs can readily engraft and generate progeny in these animals. Although immunodeficient mice have gained the broadest application in laboratory research due to the ease of access and handling of animals, humans and mice show distinct differences, especially in lifespan and body size, which are relevant to HSC transplantation. The reconstitution of human hematopoiesis in mice allows for observation for $1-2 \mathrm{y}$ after serial transplantation [10, 16, 29]; however, execution of the procedure requires a large number of mice (Fig. 1).

The aim of this study was to examine whether the transplantation of human HSCs into fetal sheep could

(Received 22 April 2014 / Accepted 28 May 2014 / Published online in J-STAGE 22 July 2014)

Address corresponding: Yutaka Hanazono (MD, PhD), Division of Regenerative Medicine, Center for Molecular Medicine, Jichi Medical

University, 3311-1 Yakushiji, Shimotsuke-shi, Tochigi 329-0498, Japan

(C)2014 Japanese Association for Laboratory Animal Science 


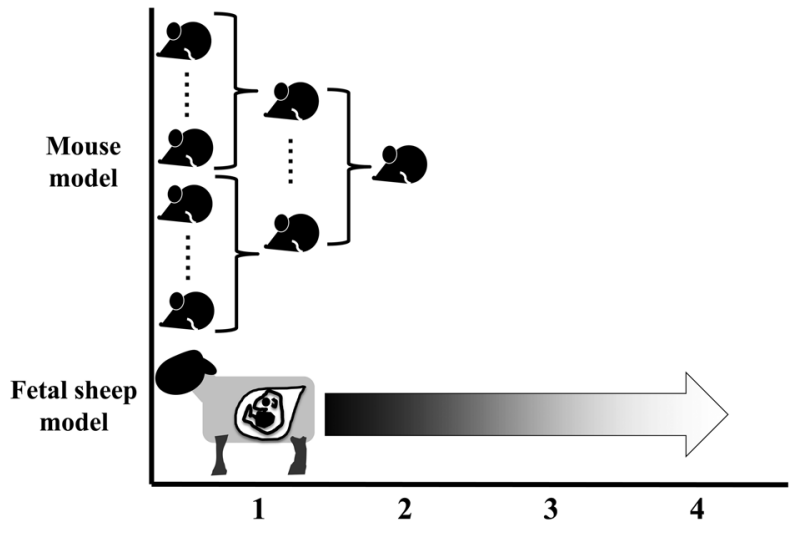

Time Post-transplantation (Years)

Fig. 1. Long-term assessment of human HSCs in vivo. In immunodeficient mice, although serial transplantation is an approach to evaluate the long-term assessment of human hematopoietic stem cells (HSCs), a large number of mice are required for the following transplantation. In contrast in sheep, the long-term assessment can be achieved in single animals. It is possible to conduct repeated bleeding and evaluation of samples at desired intervals over long periods without serial transplantation in sheep.

allow long-term engraftment of the cells in the sheep after birth. Long-term assessment of human HSCs in sheep can be performed because the large size and long lifespan of sheep allow repeated sampling of bone marrow (BM) in individual animals at desired intervals for long periods of time [1, 24, 31]. Here we report sustained engraftment of human HSCs in sheep for up to 40 months post-transplantation as assessed by clonogenic assays of the BM.

\section{Materials and Methods}

\section{Animals}

Pregnant Suffolk ewes (Japan Lamb, Hiroshima, Japan) were bred at Jichi Medical University and at Utsunomiya University Farm. All experiments in this study were performed in accordance with the Jichi Medical University Guide for Laboratory Animals and the Utsunomiya University Guide for Experimental Animals.

\section{Graft preparation}

Human cord blood (CB) was supplied by the RIKEN BioResource Center Cell Bank (Ibaraki, Japan). Human $\mathrm{CB} \mathrm{CD} 34^{+}$cells, used as hematopoietic stem cells (HSCs), were isolated by immunomagnetic separation using an anti-human CD34 microbeads kit (Miltenyi
Biotech, Auburn, CA, USA) according to the manufacturer's instructions. In a protocol (4 out of the $14 \mathrm{CB}$ samples), namely $\mathrm{HOXB} 4$ protocol, human $\mathrm{CB}$ CD $34^{+}$ cells were transduced before transplantation with a polymerase gene-defective Sendai virus vector (DNAVEC Corp., Ibaraki, Japan) that transiently expressed the human HOXB4 gene (GenBank accession No. NM 024015). The HOXB4 gene provided a selective growth advantage to transduced HSCs in vivo [4, 25, 26, 32]. The transduction was conducted by culturing the cells for 4 days in the presence of $100 \mathrm{ng} / \mathrm{ml}$ recombinant human $(\mathrm{rh})$ stem cell factor (SCF), rh Flt3 ligand (both from R\&D Systems, Minneapolis, MI, USA) and rh thrombopoietin (Kyowa Hakko-Kirin Co., Ltd., Tokyo, Japan) [1].

\section{In utero transplantation (IUT)}

The cells were transplanted into the liver of fetal sheep at 45 to 49 days of gestation (full term, 147 days). The procedures of IUT were described previously [17]. In another protocol (the BU protocol), some fetuses (4 out of the 14 sheep) received busulfan (BU, Wako Pure Chemical Industries Ltd., Osaka, Japan) via the dams intravenously at $3 \mathrm{mg} / \mathrm{kg}$ (calculated based on maternal body weight) 6 days before transplantation [2]. BU is often administered to patients as a conditioning agent before HSC transplantation [3, 21].

\section{Colony-forming unit (CFU) assay}

$\mathrm{CB} \mathrm{CD} 34^{+}$cells used for transplantation or sheep bone marrow (BM) cells post-transplantation were subjected to CFU assay. Briefly, cells were plated in a $35-\mathrm{mm}$ petri dish with $1 \mathrm{ml}$ of MethoCult $\mathrm{GF}^{+} \mathrm{H} 4435$ (StemCell Technologies, Vancouver, BC, Canada) containing SCF, granulocyte colony-stimulating factor (G-CSF), granulocyte-macrophage CSF, interleukin (IL)-3, IL-6 and erythropoietin, which were recombinant human products and purchased from StemCell Technologies. The culture conditions equivalently support the growth of ovine as well as human CFUs, and thus no difference in the efficiency of colony formation between ovine and human hematopoietic cells was observed in this assay [24]. After incubation at $37^{\circ} \mathrm{C}$ with $5 \% \mathrm{CO}_{2}$ for 14 days, colonies containing more than 50 cells were counted under an inverted light microscope [1,2]. Statistical significance of the difference in colony numbers was determined by the ANOVA-test. 
Table 1. Long-term engraftment in sheep after in-utero transplantation of human hematopoietic stem cells

\begin{tabular}{|c|c|c|c|c|c|c|c|c|c|}
\hline \multirow[b]{2}{*}{ Protocols } & \multirow[b]{2}{*}{ Animal no. } & \multicolumn{3}{|c|}{ In utero transplantation } & \multicolumn{5}{|c|}{ Engraftment $(\% \text { of human CFUs })^{a)}$} \\
\hline & & $\begin{array}{c}\text { Gestational } \\
\text { day of trans- } \\
\text { plant } \\
\text { (Full term: } \\
147 \text { days) }\end{array}$ & $\begin{array}{l}\text { Number of } \\
\text { transplanted } \\
\text { cells per } \\
\text { fetus }\left(\times 10^{5}\right)\end{array}$ & $\begin{array}{l}\text { Number of } \\
\text { transplanted } \\
\text { CD34 } \\
\text { fetus }\left(\times 10^{5}\right)\end{array}$ & $\begin{array}{l}5 \text { months } \\
\text { post IUT }\end{array}$ & $\begin{array}{c}\text { 15-17 } \\
\text { months } \\
\text { post IUT }\end{array}$ & $\begin{array}{c}20-25 \\
\text { months } \\
\text { post IUT }\end{array}$ & $\begin{array}{l}40 \text { months } \\
\text { post IUT }\end{array}$ & $\begin{array}{c}58 \\
\text { months } \\
\text { post } \\
\text { IUT }\end{array}$ \\
\hline \multirow{4}{*}{$H O X B 4^{b)}$} & Y705-1 & 49 & 5.2 & 3.8 & 0.0 & 0.0 & 0.0 & - & \\
\hline & Y705-2 & 49 & 4.5 & 4.5 & 1.1 & 2.2 & 2.2 & 2.2 & 0.0 \\
\hline & Y271-1 & 49 & 3.2 & 2.9 & 3.3 & 1.1 & 0.0 & - & \\
\hline & Y271-2 & 49 & 8.9 & 7.6 & 2.2 & 0.0 & 0.0 & - & \\
\hline \multirow{4}{*}{$\mathrm{BU}^{\mathrm{c})}$} & Y940-1 & 48 & 20.0 & 17.5 & 1.1 & -e) & & & \\
\hline & Y940-2 & 48 & 20.1 & 13.8 & 1.1 & - & 0.0 & - & \\
\hline & Y1061-1 & 48 & 7.2 & 2.8 & 2.2 & 0.0 & - & & \\
\hline & Y1061-2 & 48 & 10.7 & 5.8 & 3.3 & 0.0 & - & & \\
\hline \multirow{6}{*}{ Non-treatment ${ }^{\mathrm{d})}$} & Y1018-1 & 49 & 23.6 & 17.8 & 0.0 & - & & & \\
\hline & Y1018-2 & 49 & 15.5 & 12.0 & 0.0 & - & & & \\
\hline & Y973 & 45 & 8.6 & 5.6 & 0.0 & - & & & \\
\hline & Y936 & 47 & 7.3 & 5.4 & 0.0 & - & & & \\
\hline & W110 & 48 & 17.7 & 13.7 & 0.0 & - & & & \\
\hline & Y955 & 48 & 13.3 & 10.1 & 0.0 & - & & & \\
\hline
\end{tabular}

a) Percentage of human CFUs was calculated by dividing the number of CFUs positive for the human-specific $\beta 2$-microglobulin gene sequence by the total number of CFUs being analyzed in the bone marrow. ${ }^{\text {b) }}$ In the HOXB4 protocol, human CD $34^{+}$cells transduced with HoxB4 were transplanted into non-con ditioned fetal sheep [1]. ${ }^{\text {c) }}$ In the BU protocol, BU was administered 6 days before IUT of non-transduced human $\mathrm{CD} 34^{+}$cells [2]. ${ }^{\text {d) }}$ In the non-treatment protocol, non-transduced human $\mathrm{CD} 34^{+}$cells were transplanted into nonconditioned fetal s heep [1,2]. ${ }^{\text {e) }}$ Sheep Y940-1 unexpectedly died from an accident during the procedures of bone marrow aspiration. CFU, colony-forming unit; BU, busulfan; IUT, in utero transplantation.

\section{Assessment of human engraftment}

To evaluate the engraftment of human cells, BM was aspirated from the iliac bone of lambs using a 13-gauge biopsy needle (Jamshidi, CareFusion, San Diego, USA), under local anesthesia with $2 \%$ lidocain (Xylocaine, AstraZeneca, Tokyo, Japan). BM cells were harvested by removing red blood cells with ACK lysis buffer (155 $\mathrm{mM} \mathrm{NH}_{4} \mathrm{Cl}, 100 \mathrm{mM} \mathrm{KHCO}_{3}$, and 1 mM EDTA) (Wako Pure Chemical Industries, Ltd.). In vitro colony formation assay of sheep BM cells after transplantation was conducted as described above (in the section of $C F U$ assay). Each colony was derived from a single human or sheep hematopoietic progenitor cell. DNA of each colony was subjected to polymerase chain reaction (PCR) to identify human colonies [24]. First, each colony was plucked into $50 \mu \mathrm{l}$ of distilled water and digested with $20 \mu \mathrm{g} / \mathrm{ml}$ proteinase K (Takara, Shiga, Japan) at $55^{\circ} \mathrm{C}$ for $2 \mathrm{~h}$, followed by $99^{\circ} \mathrm{C}$ for $10 \mathrm{~min}$, to extract DNA. Each DNA sample $(5 \mu \mathrm{l})$ was used for a nested PCR to identify the human $\beta 2$-microglobulin-specific sequences $[1,2]$. The outer primer set was 5'-CAGGTTTACTCACGTCATCCAG-3' and 5'-GGTTCACACGGCAGGCATACTC-3', and the inner primer set was 5'-GTCTGGGTTTCATCCATCCG-3' and 5'- GGTGAATTCAGTGTAGTACAAG-3'. The amplification conditions for the outer PCR were $95^{\circ} \mathrm{C}$ for $30 \mathrm{~s}, 58^{\circ} \mathrm{C}$ for $30 \mathrm{~s}$, and $72^{\circ} \mathrm{C}$ for $30 \mathrm{~s}$ for 25 cycles. The outer PCR products were purified using a QIA quick PCR purification kit (Qiagen, Chatsworth, CA, USA). The amplification conditions for the inner PCR were $95^{\circ} \mathrm{C}$ for $30 \mathrm{~s}$, $58^{\circ} \mathrm{C}$ for $30 \mathrm{~s}$, and $72^{\circ} \mathrm{C}$ for $30 \mathrm{~s}$ for 30 cycles. Simultaneous PCR for the $\beta$-actin sequence was also performed to verify the DNA amplification of each sample. The primer sequences of either humans or sheep were $5^{\prime}$-GTCACCCACACTGTGCCCATCTACG-3' and 5'-GCCATCTCCTGCTCGAAGTC-3'. The amplification conditions were $94^{\circ} \mathrm{C}$ for $30 \mathrm{~s}, 55^{\circ} \mathrm{C}$ for $30 \mathrm{~s}$, and $72^{\circ} \mathrm{C}$ for $30 \mathrm{~s}$ for 40 cycles. The amplified human $\beta 2$ microglobulin (133 bp) and $\beta$-actin (209 bp) products were resolved by $2 \%$ agarose gel and visualized by ethidium bromide staining. The engraftment efficiency of human hematopoietic cells was expressed as the ratio of the number of human-derived colonies to the total number of colonies.

\section{Results}

Frozen human cord blood (CB) was obtained from RIKEN Cell Bank. The cells were thawed, and a range of $2.8 \times 10^{5}-17.8 \times 10^{5}$ of $\mathrm{CD} 34^{+}$cells were isolated 


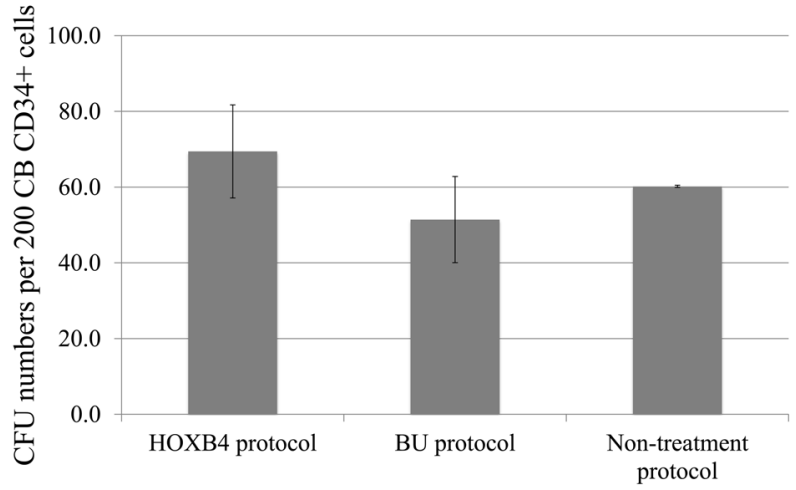

Fig. 2. In vitro $\mathrm{CFU}$ assay for validating the viability and functionality of transplanted $\mathrm{CD} 34^{+}$cells. In order to assess the viability and functionality of human cord blood (CB) $\mathrm{CD} 34^{+}$cells in the three protocols, colony forming-unit (CFU) assays of each $\mathrm{CB}$ CD $34^{+}$sample were conducted. Results are shown as mean \pm standard deviation. Statistical significance was determined by ANOVA test. No significant difference was observed among the three protocols.

for use as hematopoietic stem cells (HSCs) for transplantation in fetal sheep. The cells were transplanted into 14 fetal sheep at 45 to 49 days of gestation. Two protocols were used in some of the sheep [1, 2]. Four fetal sheep received $H O X B 4$-transduced $\mathrm{CD} 34^{+}$cells (the HOXB4 protocol) [1]. Another 4 fetal sheep were subjected to non-myeloablative conditioning with busulfan (the BU protocol) [2]. The two protocols, which exhibited comparable effects on the short-term engraftment potential of HSCs (up to 5 months post-transplantation) $[1,2]$.

The number of transplanted $\mathrm{CD} 34^{+}$cells varied widely among the 14 sheep from $2.8 \times 10^{5}$ to $17.8 \times 10^{5}$, and the maximal cell number was about 6.4 times larger than the minimum cell number (Table 1). However, the numbers of mononuclear cells and $\mathrm{CD} 34^{+}$cells that were transplanted into each fetus did not differ significantly among the three protocols (Table $1 ; P=0.06$ and 0.14 , respectively).

To verify the viability and functionality of the transplanted cells, we performed CFU assays and compared the results of the two modified protocols and the original protocol (Fig. 2). The $\mathrm{CB} \mathrm{CD} 34^{+}$cells formed multilineage colonies (CFU-G, M, GM and BFU-E) at similar efficiencies as those shown in other previous reports $[7,22,23]$. There was no significant difference in the number of CFUs among the three protocols $(P=0.09)$, suggesting comparable viability and functionality of $\mathrm{CB}$

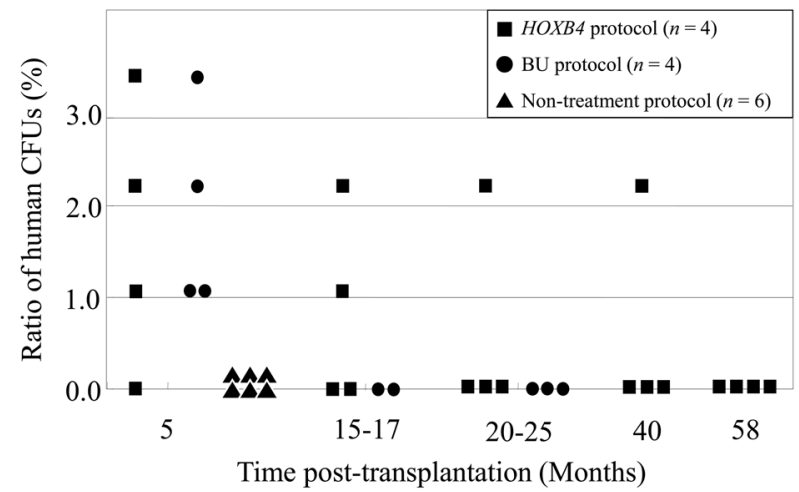

Fig. 3. Long-term follow-up of human HSC engraftment after IUT in sheep. Human cord blood (CB) CD34 ${ }^{+}$cells were transduced with $H O X B 4$ and transplanted into intact (non-conditioned) fetal sheep (HOXB4 protocol, $\square)$. Intact (nontransduced) human $\mathrm{CB} \mathrm{CD} 34^{+}$cells were transplanted into fetal sheep conditioned with busulfan (BU) (BU protocol, $\bullet$ ). In addition, intact human $\mathrm{CB} C D 34^{+}$cells were transplanted into intact fetal sheep (non-treatment protocol, $\mathbf{\Delta}$ ). The scatter plots show percentages of human colony-forming units (CFUs) at the indicated months after in utero transplantation (IUT). The percentage of human CFUs was calculated by dividing the number of CFUs expressing the human $\beta 2$-microglobulin gene by the total number of CFUs being analyzed in the bone marrow.

$\mathrm{CD}^{+} 4^{+}$cells transplanted in all three protocols in the present study. Regarding the HOXB4 protocol, the transduction of $\mathrm{CB} \mathrm{CD} 34^{+}$cells with the HOXB4 gene did not affect the myeloid/erythroid ratio as assessed by $\mathrm{CFU}$ assays. It was about 10:1 either before or after the HOXB4 transduction.

A total of 14 ovine fetuses received transplantation, and no abortion was observed in this study. After the birth of lambs, the BM of each lamb was tested to identify the presence of human CFUs (Table 1). In the nontreatment group, human CFUs were not detected after birth $[1,2]$. In the BU protocol, human CFUs were detected up to 5 months post-transplantation [2]. Notably, in the HOXB4 protocol, they were detectable up to 40 months post-transplantation (Fig. 3). All of the sheep lost human CFUs by 58 months post-IUT. Thus, human hematopoietic cells could engraft in sheep for up to 40 months. However, extremely low levels $(<0.01 \%)$ of transplant-derived cells were detected in the peripheral blood (PB) of all of the sheep, in good agreement with the results in our previous studies and other reports $[1,2,18-21,24,28,30]$. 


\section{Discussion}

In this study, we showed long-term engraftment of human HSCs in sheep for up to 40 months through the HOXB 4 protocol; that is, we detected human clonogenic hematopoietic colonies in sheep BM for the period. Previous other studies just showed the presence of human cells in the PB by flow cytometry with anti-human CD45 antibody or other human specific hematopoietic markers, but did not conduct clonogenic studies [31]. This is the first report showing the evidence of long-term engraftment of human HSCs in sheep through clonogenic assays.

In the original non-treatment protocol of our sheep IUT (i.e., without genetic transduction or conditioning), human $\mathrm{CB}$ CD $34^{+}$cells could not mediate engraftment for longer than 5 months post-transplantation $[1,2]$. However, Zanjani et al. [31] demonstrated successful cell engraftment for up to $3.6 \mathrm{y}$ after the transplantation of human fetal liver HSCs even without genetic transduction or conditioning. There are several possible explanations for this discrepancy, one of which is the route of injection. Zanjani et al. [31] injected cells into the abdominal cavity of fetal sheep, whereas we injected cells into the liver of fetal sheep. However, we previously showed that no significant differences in the engraftment efficiencies of human HSCs existed among the animals receiving intrahepatic, intraperitoneal and intravascular injections [28]. Another possibility is the gestational day of injection. Zanjani et al. [27] injected cells at days 51-71 of gestation, whereas we injected cells at days 45-49 of gestation. However, according to our previous studies [1, 2, 24, 28], the gestational day of fetal sheep for performing the cell injection (45-79 gestational days) did not affect the engraftment efficiency, either. One more possible explanation for this discrepancy is the source of cells used in the studies, as suggested by Noia et al. [18]. Zanjani et al. [31] used human fetal liver mononuclear cells, whereas we used human $\mathrm{CB}$ CD34 ${ }^{+}$ cells. Thus, it is reasonable that the transplantation of ontogenetically matched HSCs (fetal-to-fetal) results in a better outcome than that of ontogenetically mismatched HSCs (neonatal-to-fetal).

A very low level of transplant-derived cells was present $(<0.01 \%)$ in the PB of the sheep, unlike in the PB of immunodeficient mice $[14,15]$. This issue has been repeatedly mentioned in other studies about sheep IUT of human HSCs [1, 2, 17, 19, 20, 24, 28, 30]. A possible explanation is that the low $\mathrm{PB}$ chimerism is just reflected by the low BM chimerism (1-3\%). Another possible explanation is xenogeneic mismatch between human HSCs and sheep stromal cells, and the mismatch may be larger than that between human HSCs and mouse stromal cells. The stromal trophic stimulations from the sheep microenvironment, such as cytokine secretion and adherent molecules, would not allow human hematopoietic differentiation, hampering human terminally differentiated cells to appear in the PB. The other possibility is attributed to innate immunity. That is the case when human HSCs were transplanted into even the most immunodeficient NOG mice. The numbers of human red blood cells (RBCs) and platelets were extremely low in PB in spite of high levels of human HSC-derived progenitors in $\mathrm{BM}[12,13]$. The poor reconstitution of human RBCs and platelets was a result of phagocytosis by macrophages $[12,13]$. Though the absence of human blood cells in the PB, the fetal sheep model is suitable for long-term assessment of human HSCs. The fetal sheep model should provide a unique perspective for evaluating the engraftment and behavior of human HSCs.

\section{Acknowledgments}

We thank Yoshihiro Kitano (an ex-member in National Center for Child Health and Development, Tokyo, Japan), Satoshi Hayashi (Tokyo Mother's Clinic), Hiroaki Shibata (Tsukuba Primate Research Center, Ibaraki, Japan), Shigeo Masuda, Yujiro Tanaka, Yukiko Kishi, Yoshihisa Mizukami, Shuh-hei Fujishiro, Yutaka Furukawa, Hozumi Tanaka (Jichi Medical University, Tochigi, Japan), Suguru Nitta and Asuka Hara (Utsunomiya University) for excellent technical assistance and helpful discussions.

\section{Support and Financial Disclosure Declaration}

This study was supported partly by Japan Science and Technology Agency (JST) Yamanaka iPS Cell Special Project to Y.H., JST Center Network for Realization of Regenerative Medicine to YH, and by KAKENHI from Ministry of Education, Culture, Sports, Science and Technology of Japan to T.A., Y.H. and Y.N. The authors declare no competing financial interests. 


\section{References}

1. Abe, T., Masuda, S., Ban, H., Hayashi, S., Ueda, Y., Inoue, M., Hasegawa, M., Nagao, Y., and Hanazono, Y. 2011. Ex vivo expansion of human HSCs with Sendai virus vector expressing HoxB4 assessed by sheep in utero transplantation. Exp. Hematol. 39: 47-54. [Medline] [CrossRef]

2. Abe, T., Masuda, S., Tanaka, Y., Nitta, S., Kitano, Y., Hayashi, S., Hanazono, Y., and Nagao, Y. 2012. Maternal administration of busulfan before in utero transplantation of human hematopoietic stem cells enhances engraftments in sheep. Exp. Hematol. 40: 436-444. [Medline] [CrossRef]

3. Aiuti, A., Slavin, S., Aker, M., Ficara, F., Deola, S., Mortellaro, A., Morecki, S., Andolfi, G., Tabucchi, A., Carlucci, F., Marinello, E., Cattaneo, F., Vai, S., Servida, P., Miniero, R., Roncarolo, M.G., and Bordignon, C. 2002. Correction of ADA-SCID by stem cell gene therapy combined with nonmyeloablative conditioning. Science 296: 2410-2413. [Medline] [CrossRef]

4. Antonchuk, J., Sauvageau, G., and Humphries, R.K. 2002. HOXB4-induced expansion of adult hematopoietic stem cells ex vivo. Cell 109: 39-45. [Medline] [CrossRef]

5. Bhatia, M., Bonnet, D., Murdoch, B., Gan, O.I., and Dick, J.E. 1998. A newly discovered class of human hematopoietic cells with SCID-repopulating activity. Nat. Med. 4: 10381045. [Medline] [CrossRef]

6. Bhatia, M., Wang, J.C., Kapp, U., Bonnet, D., and Dick, J.E. 1997. Purification of primitive human hematopoietic cells capable of repopulating immune-deficient mice. Proc. Natl. Acad. Sci. USA 94: 5320-5325. [Medline] [CrossRef]

7. Conneally, E., Cashman, J., Petzer, A., and Eaves, C. 1997. Expansion in vitro of transplantable human cord blood stem cells demonstrated using a quantitative assay of their lympho-myeloid repopulating activity in nonobese diabetic-scid/ scid mice. Proc. Natl. Acad. Sci. USA 94: 9836-9841. [Medline] [CrossRef]

8. Doulatov, S., Notta, F., Laurenti, E., and Dick, J.E. 2012. Hematopoiesis: a human perspective. Cell Stem Cell 10: 120-136. [Medline] [CrossRef]

9. Higuchi, Y., Kawai, K., Yamamoto, M., Kuronuma, M., Ando, Y., Katano, I., Nakamura, M., and Suemizu, H. 2014. A novel enhanced green fluorescent protein-expressing NOG mouse for analyzing the microenvironment of xenograft tissues. Exp. Anim. 63: 55-62. [Medline] [CrossRef]

10. Hope, K.J., Jin, L., and Dick, J.E. 2004. Acute myeloid leukemia originates from a hierarchy of leukemic stem cell classes that differ in self-renewal capacity. Nat. Immunol. 5: 738-743. [Medline] [CrossRef]

11. Horn, P.A., Morris, J.C., Neff, T., and Kiem, H.P. 2004. Stem cell gene transfer - efficacy and safety in large animal studies. Mol. Ther. 10: 417-431. [Medline] [CrossRef]

12. $\mathrm{Hu}, \mathrm{Z}$. and Yang, Y.G. 2012. Full reconstitution of human platelets in humanized mice after macrophage depletion. Blood 120: 1713-1716. [Medline] [CrossRef]

13. Hu, Z., Van Rooijen, N., and Yang, Y.G. 2011. Macrophages prevent human red blood cell reconstitution in immunodeficient mice. Blood 118: 5938-5946. [Medline] [CrossRef]

14. Ishii, M., Matsuoka, Y., Sasaki, Y., Nakatsuka, R., Taka- hashi, M., Nakamoto, T., Yasuda, K., Matsui, K., Asano, H., Uemura, Y., Tsuji, T., Fukuhara, S., and Sonoda, Y. 2011. Development of a high-resolution purification method for precise functional characterization of primitive human cord blood-derived CD34-negative SCID-repopulating cells. Exp. Hematol. 39: 203-213, e1. [Medline] [CrossRef]

15. Ito, M., Hiramatsu, H., Kobayashi, K., Suzue, K., Kawahata, M., Hioki, K., Ueyama, Y., Koyanagi, Y., Sugamura, K., Tsuji, K., Heike, T., and Nakahata, T. 2002. NOD/SCID/ gamma(c)(null) mouse: an excellent recipient mouse model for engraftment of human cells. Blood 100: 3175-3182. [Medline] [CrossRef]

16. Muguruma, Y., Matsushita, H., Yahata, T., Yumino, S., Tanaka, Y., Miyachi, H., Ogawa, Y., Kawada, H., Ito, M., and Ando, K. 2011. Establishment of a xenograft model of human myelodysplastic syndromes. Haematologica 96: 543-551. [Medline] [CrossRef]

17. Nagao, Y., Abe, T., Hasegawa, H., Tanaka, Y., Sasaki, K., Kitano, Y., Hayashi, S., and Hanazono, Y. 2009. Improved efficacy and safety of in utero cell transplantation in sheep using an ultrasound-guided method. Cloning Stem Cells 11: 281-285. [Medline] [CrossRef]

18. Noia, G., Ligato, M.S., Cesari, E., Visconti, D., Fortunato, G., Tintoni, M., Mappa, I., Greco, C., Caristo, M.E., Bonanno, G., Corallo, M., Minafra, L., Perillo, A., Terzano, M., Rutella, S., Leone, G., Scambia, G., Michejda, M., and Mancuso, S. 2008. Source of cell injected is a critical factors for short and long engraftment in xeno-transplantation. Cell Prolif. 41: 41-50. [Medline] [CrossRef]

19. Noia, G., Pierelli, L., Bonanno, G., Monego, G., Perillo, A., Rutella, S., Cavaliere, A.F., De Santis, M., Ligato, M.S., Fortunato, G., Scambia, G., Terzano, G.M., Iannace, E., Zelano, G., Michetti, F., Leone, G., and Mancuso, S. 2003. A novel route of transplantation of human cord blood stem cells in preimmune fetal sheep: the intracelomic cavity. Stem Cells 21: 638-646. [Medline] [CrossRef]

20. Noia, G., Pierelli, L., Bonanno, G., Monego, G., Perillo, A., Rutella, S., Cavaliere, A.F., Straface, G., Fortunato, G., Cesari, E., Scambia, G., Terzano, M., Iannace, E., Zelano, G., Michetti, F., Leone, G., and Mancuso, S. 2004. The intracoelomic route: a new approach for in utero human cord blood stem cell transplantation. Fetal Diagn. Ther. 19: 13-22. [Medline] [CrossRef]

21. Ott, M.G., Schmidt, M., Schwarzwaelder, K., Stein, S., Siler, U., Koehl, U., Glimm, H., Kühlcke, K., Schilz, A., Kunkel, H., Naundorf, S., Brinkmann, A., Deichmann, A., Fischer, M., Ball, C., Pilz, I., Dunbar, C., Du, Y., Jenkins, N.A., Copeland, N.G., Lüthi, U., Hassan, M., Thrasher, A.J., Hoelzer, D., von Kalle, C., Seger, R., and Grez, M. 2006. Correction of X-linked chronic granulomatous disease by gene therapy, augmented by insertional activation of MDS1-EVI1, PRDM16 or SETBP1. Nat. Med. 12: 401-409. [Medline] [CrossRef]

22. Piacibello, W., Sanavio, F., Severino, A., Danè, A., Gammaitoni, L., Fagioli, F., Perissinotto, E., Cavalloni, G., Kollet, O., Lapidot, T., and Aglietta, M. 1999. Engraftment in nonobese diabetic severe combined immunodeficient mice of human CD34(+) cord blood cells after ex vivo expansion: 
evidence for the amplification and self-renewal of repopulating stem cells. Blood 93: 3736-3749. [Medline]

23. Peled, A., Petit, I., Kollet, O., Magid, M., Ponomaryov, T., Byk, T., Nagler, A., Ben-Hur, H., Many, A., Shultz, L., Lider, O., Alon, R., Zipori, D., and Lapidot, T. 1999. Dependence of human stem cell engraftment and repopulation of NOD/ SCID mice on CXCR4. Science 283: 845-848. [Medline] [CrossRef]

24. Sasaki, K., Nagao, Y., Kitano, Y., Hasegawa, H., Shibata, H., Takatoku, M., Hayashi, S., Ozawa, K., and Hanazono, Y. 2005. Hematopoietic microchimerism in sheep after in utero transplantation of cultured cynomolgus embryonic stem cells. Transplantation 79: 32-37. [Medline] [CrossRef]

25. Sauvageau, G., Thorsteinsdottir, U., Eaves, C.J., Lawrence, H.J., Largman, C., Lansdorp, P.M., and Humphries, R.K. 1995. Overexpression of HOXB4 in hematopoietic cells causes the selective expansion of more primitive populations in vitro and in vivo. Genes Dev. 9: 1753-1765. [Medline] [CrossRef]

26. Schiedlmeier, B., Klump, H., Will, E., Arman-Kalcek, G., Li, Z., Wang, Z., Rimek, A., Friel, J., Baum, C., and Ostertag, W. 2003. High-level ectopic HOXB4 expression confers a profound in vivo competitive growth advantage on human cord blood CD $34^{+}$cells, but impairs lymphomyeloid differentiation. Blood 101: 1759-1768. [Medline] [CrossRef]

27. Skopal-Chase, J.L., Pixley, J.S., Torabi, A., Cenariu, M.C., Bhat, A., Thain, D.S., Frederick, N.M., Groza, D.M., and
Zanjani, E.D. 2009. Immune ontogeny and engraftment receptivity in the sheep fetus. Fetal Diagn. Ther. 25: 102-110. [Medline] [CrossRef]

28. Tanaka, Y., Masuda, S., Abe, T., Hayashi, S., Kitano, Y., Nagao, Y., and Hanazono, Y. 2010. Intravascular route is not superior to an intraperitoneal route for in utero transplantation of human hematopoietic stem cells and engraftment in sheep. Transplantation 90: 462-463. [Medline] [CrossRef]

29. Yahata, T., Takanashi, T., Muguruma, Y., Ibrahim, A.A., Matsuzawa, H., Uno, T., Sheng, Y., Onizuka, M., Ito, M., Kato, S., and Ando, K. 2011. Accumulation of oxidative DNA damage restricts the self-renewal capacity of human hematopoietic stem cells. Blood 118: 2941-2950. [Medline] [CrossRef]

30. Young, A.J., Holzgreve, W., Dudler, L., Schoeberlein, A., and Surbek, D.V. 2003. Engraftment of human cord bloodderived stem cells in preimmune ovine fetuses after ultrasound-guided in utero transplantation. Am. J. Obstet. Gynecol. 189: 698-701. [Medline] [CrossRef]

31. Zanjani, E.D., Flake, A.W., Rice, H., Hedrick, M., and Tavassoli, M. 1994. Long-term repopulating ability of xenogeneic transplanted human fetal liver hematopoietic stem cells in sheep. J. Clin. Invest. 93: 1051-1055. [Medline] [CrossRef]

32. Zhang, X.B., Beard, B.C., Beebe, K., Storer, B., Humphries, R.K., and Kiem, H.P. 2006. Differential effects of HOXB4 on nonhuman primate short- and long-term repopulating cells. PLoS Med. 3: e173. [Medline] [CrossRef] 